\title{
Palonosetron for the prevention of chemotherapy- induced nausea and vomiting: approval and efficacy
}

\author{
This article was published in the following Dove Press journal: \\ Cancer Management and Research \\ 9 December 2009 \\ Number of times this article has been viewed
}

\section{Rudolph M Navari \\ Indiana University School of Medicine South Bend, South Bend, IN USA}

\begin{abstract}
Chemotherapy-induced nausea and vomiting (CINV) is associated with a significant deterioration in quality of life. The emetogenicity of the chemotherapeutic agents, repeated chemotherapy cycles, and patient characteristics (female gender, younger age, low alcohol consumption, history of motion sickness) are the major risk factors for CINV. This review provides a detailed description of palonosetron, a second-generation 5-hydroxytryptamine $3\left(5-\mathrm{HT}_{3}\right)$ receptor antagonist. The chemistry and pharmacology of palonosetron are described, as well as the initial and recent clinical trials. Palonosetron has a longer half-life and a higher binding affinity than the first-generation $5-\mathrm{HT}_{3}$ receptor antagonists. Palonosetron has been approved for the prevention of acute CINV in patients receiving either moderately or highly emetogenic chemotherapy and for the prevention of delayed CINV in patients receiving moderately emetogenic chemotherapy. In recent studies, compared to the first-generation 5-HT receptor antagonists, palonosetron in combination with dexamethasone demonstrated better control of delayed CINV in patients receiving highly emetogenic chemotherapy. There were no clinically relevant adverse reactions reported in the palonosetron clinical trials which were different from the common reactions reported for the 5- $\mathrm{HT}_{3}$ receptor antagonist class. Due to its efficacy in controlling both acute and delayed CINV, palonosetron may be very effective in the clinical setting of multiple-day chemotherapy and bone marrow transplantation.
\end{abstract}

Keywords: anti-emetics, chemotherapy-induced nausea and vomiting, serotonin receptor antagonists, palonosetron

\section{Introduction}

Chemotherapy-induced nausea and vomiting (CINV) is a distressing and common adverse event associated with cancer treatment. Patients consistently report that vomiting and nausea are among the most unpleasant and distressing aspects of chemotherapy. ${ }^{1}$ Even one or two emetic episodes are associated with a significant deterioration in the quality of life, as well as physical and cognitive functioning, and may cause patients to delay or refuse potentially curative therapy. ${ }^{2-4}$

The individual patient risk of CINV is associated with the type of chemotherapy administered ${ }^{5}$ and specific patient characteristics. ${ }^{6}$ Agents such as cisplatin and dacarbazine have high emetogenic potential with emesis in nearly all patients, while carboplatin, anthracyclines, and cyclophosphamide are considered moderately emetogenic with emesis in $>70 \%$ of patients. Etoposide, gemcitabine, and mitoxantrone are of low emetogenic potential with emesis in $10 \%$ to $70 \%$ of patients. Age $<50$, female gender, history of low prior chronic alcohol intake, history of motion sickness, and emesis during pregnancy are significant risk factors for CINV.
Correspondence: Rudolph M Navari Department of Medicine, Indiana University School of Medicine South Bend, 1234 Notre Dame Avenue, South Bend, IN 46617 USA

Tel + | 574-63 I-3793

Fax + | 574-63I-6857

Email navari. I@nd.edu 
Studies on the prevention of CINV report on 3 distinct but related CINV: ${ }^{6}$ (1) acute CINV (first 24 hours); (2) delayed CINV (24 to 120 hours); and (3) overall CINV (0 to 120 hours). Although patients can experience CINV for longer than 5 days post-chemotherapy, the majority of studies have used 120 hours as the measurement period.

Despite the introduction of more effective antiemetic agents (5-hydroxytryptamine-3 receptor [5-HT $]$ antagonists and neurokinin-1 [NK-1] receptor antagonists), emesis and nausea remain significant complications of chemotherapy. This paper reviews the evolving role of palonosetron for the prevention and treatment of CINV. The report includes a description of the chemistry and the pharmacology of palonosetron, a review of the primary clinical trials used for the US Food and Drug Administration (FDA) approval of palonosetron, as well as a review of recent, new clinical trials which may suggest additional clinical indications.

\section{Serotonin $\left(5-\mathrm{HT}_{3}\right)$ receptor antagonists}

Serotonin receptors, specifically the $5-\mathrm{HT}_{3}$ receptors, exist in the central nervous system and in the gastrointestinal (GI) tract. The first-generation $5-\mathrm{HT}_{3}$ receptor antagonists, such as dolasetron, granisetron, ondansetron, and tropisetron, appear to act through both the central nervous system and the GI tract via the vagus and splanchnic nerves. The main toxicities of these $5-\mathrm{HT}_{3}$ receptor antagonists consist only of a mild headache, mild constipation, and occasional diarrhea.

Table 1 shows the 5-HT 3 receptor antagonists currently in use. The first-generation serotonin $\left(5-\mathrm{HT}_{3}\right)$ receptor antagonists dolasetron, ${ }^{6}$ granisetron, ${ }^{6}$ ondansetron, ${ }^{6}$ tropisetron, ${ }^{7}$ azasetron $^{8}$ and ramosetron ${ }^{9}$ are equivalent in efficacy and toxicities when used in the recommended doses and compete only on an economic basis. ${ }^{10}$ They have not been associated with major toxicities. A prolongation of cardiac conduction intervals has been reported for this class of compounds, ${ }^{10-13}$ dolasetron being more extensively studied than granisetron and ondansetron, but there have been no reported significant clinical cardiovascular adverse events. ${ }^{14}$

The first-generation 5- $\mathrm{HT}_{3}$ receptor antagonists have not been as effective against delayed emesis as they are against acute CINV. ${ }^{15-20}$ The available studies show that with corticosteroids alone, or combined with either metoclopramide or a $5-\mathrm{HT}_{3}$ receptor antagonist in patients receiving cisplatin, the incidence of delayed CINV has been reduced, but remains a significant problem. ${ }^{21}$ The first-generation $5-\mathrm{HT}_{3}$ receptor antagonists do not add significant efficacy to that obtained by dexamethasone alone in the control of delayed emesis. ${ }^{18}$
Table I Serotonin antagonists and dosage before chemotherapy ${ }^{\mathrm{a}}$

\begin{tabular}{|c|c|c|}
\hline Antiemetic & Route & Dosage \\
\hline Azasetron $^{b}$ & iv & $10 \mathrm{mg}$ \\
\hline \multirow[t]{2}{*}{ Dolasetron } & iv & $100 \mathrm{mg}$ or $1.8 \mathrm{mg} / \mathrm{kg}$ \\
\hline & po & $100 \mathrm{mg}$ \\
\hline \multirow[t]{3}{*}{ Granisetron } & iv & $10 \mu g / k g$ or I mg \\
\hline & po & 2 mg (or I mg twice daily) \\
\hline & Transdermal & $3.1 \mathrm{mg} / 24 \mathrm{~h}$ up to 7 days \\
\hline \multirow{5}{*}{ Ondansetron } & iv & $0.15 \mathrm{mg} / \mathrm{kg}$ or $32 \mathrm{mg}$ \\
\hline & po & $\begin{array}{l}24 \mathrm{mg} \text { (highly emetogenic } \\
\text { chemotherapy agents) }\end{array}$ \\
\hline & & $8 \mathrm{mg}$ (moderately emetogenic \\
\hline & & chemotherapy agents \\
\hline & ODT & $4 \mathrm{mg}$ and $8 \mathrm{mg}$ \\
\hline \multirow[t]{2}{*}{ Palonosetron } & iv & $0.25 \mathrm{mg}$ \\
\hline & po & $0.50 \mathrm{mg}$ \\
\hline Ramosetron ${ }^{\mathrm{b}}$ & iv & $0.30 \mathrm{mg}$ \\
\hline Tropisetron ${ }^{\mathrm{b}}$ & iv or po & $5 \mathrm{mg}$ \\
\hline
\end{tabular}

${ }^{2}$ The same doses are used for highly and moderately emetic chemotherapy. ${ }^{\text {DNot }}$ available for use in the US.

Abbreviations: iv, intravenous; ODT, orally disintegrating tablets; po, by mouth.

Hickok et a ${ }^{20}$ reported that the first-generation $5-\mathrm{HT}_{3} \mathrm{~s}$ used in the delayed period were no more effective than prochlorperazine in controlling nausea. A recent meta-analysis ${ }^{19}$ showed that there was neither clinical evidence nor considerations of cost effectiveness to justify using the first-generation $5-\mathrm{HT}_{3}$ antagonists beyond 24 hours after chemotherapy for the prevention of delayed emesis.

The second-generation 5- $\mathrm{HT}_{3}$ receptor antagonist palonosetron was approved for the prevention of CINV based on a number of phase II-III trials ${ }^{22-25}$ in 2003. Recent studies ${ }^{26}$ indicate that it has extended efficacy in controlling delayed CINV compared to the first-generation $5-\mathrm{HT}_{3}$ receptor antagonists.

\section{Palonosetron clinical studies}

Palonosetron is a $5-\mathrm{HT}_{3}$ receptor antagonist which has antiemetic activity at both central and GI sites. ${ }^{27}$ In comparison to the older $5-\mathrm{HT}_{3}$ receptor antagonists, it has a higher binding affinity to the $5-\mathrm{HT}_{3}$ receptors (Table 2 ), a higher potency, a significantly longer half-life (approximately 40 hours, 4 to 10 times longer than that of dolasetron, granisetron, or ondansetron) (Table 2), and an excellent safety profile as demonstrated in a number of phase II-III studies. ${ }^{22-26,28-32}$

\section{Initial studies}

Phase II

In a dose-finding study, ${ }^{24}$ a single intravenous dose of palonosetron $(0.3-90 \mu \mathrm{g} / \mathrm{kg})$ was given to 161 patients receiving 
Table $2 \mathrm{HHT}_{3}$ receptor antagonists' binding affinity and plasma half-life ${ }^{\mathrm{a}}$

\begin{tabular}{lll}
\hline Drug & pKi $[-\log ($ Ki) $)$ & $\begin{array}{l}\text { Half-life } \\
\text { (hours) }\end{array}$ \\
\hline Palonosetron & 10.45 & 40 \\
Ondansetron & 8.39 & 4 \\
Granisetron & 8.91 & 9 \\
Dolasetron+ & 7.60 & 7.3 \\
\hline
\end{tabular}

${ }^{a}$ Half-life reported for hydrodolasetron, the active metabolite of dolasetron.

cisplatin $\left(\geq 70 \mathrm{mg} / \mathrm{m}^{2}\right)$. Approximately $50 \%$ of the patients who received $3 \mu \mathrm{g} / \mathrm{kg}$ had a complete response (CR) (no emesis, no need for rescue) for the first 24 hours postchemotherapy, with no significant palonosetron-related toxicities. There was no improvement in CR in patients who received $\geq 3 \mu \mathrm{g} / \mathrm{kg}$, and patients did not receive corticosteroids prior to chemotherapy. This dose-finding study demonstrated that the effective dose was $\geq 0.25 \mathrm{mg}$. ${ }^{24}$

\section{Phase III}

Eisenberg et $\mathrm{a}^{22}$ reported that 592 patients receiving moderately emetogenic chemotherapy (MEC) were randomized to receive a single intravenous dose of dolasetron $(100 \mathrm{mg})$ or palonosetron $(0.25 \mathrm{mg}$ or $0.75 \mathrm{mg})$. Sixty-three percent of the patients who received $0.25 \mathrm{mg}$ of palonosetron had a CR 24 hours post-chemotherapy (acute period), compared to $53 \%$ of patients who received dolasetron, a clinically significant difference, though not statistically superior in this trial. CR in the delayed period (24 to 120 hours postchemotherapy) was statistically and clinically significantly improved in patients who received the $0.25 \mathrm{mg}$ dose of palonosetron (54\%), compared to the patients who received dolasetron (39\%). The prevention of nausea (no nausea on 4-point Likert scale) was numerically better on days 1 through 5 and significantly improved on days 2 and 3 of the delayed period, as well, in the patients who received $0.25 \mathrm{mg}$ of palonosetron. The randomization was stratified by factors known to significantly affect response rates, such as gender, previous chemotherapy exposure, and use of corticosteroids.

A similar study of 570 patients receiving MEC was randomized to receive a single intravenous dose of palonosetron $(0.25 \mathrm{mg}$ or $0.75 \mathrm{mg})$ or ondansetron $(32 \mathrm{mg}){ }^{23}$ CR was significantly better in both the acute and delayed period in the patients who received $0.25 \mathrm{mg}$ of palonosetron $(81 \%, 74 \%)$ compared to ondansetron $(69 \%, 55 \%)$. The prevention of nausea was significantly better for palonosetron only on days 3 through 5 of the delayed period. There were no significant differences in toxicities among the patient groups.

In these 2 large studies ${ }^{22,23}$ in patients receiving MEC, $\mathrm{CR}$ was improved in the acute and the delayed period for the patients who received $0.25 \mathrm{mg}$ of palonosetron alone compared to either ondansetron alone (374 patients; acute: $81.0 \%$ versus $68.6 \%, P=0.008$; delayed: $74.1 \%$ versus $55.1 \%, P<0.001)^{23}$ or dolasetron alone (380 patients; acute: $63.0 \%$ versus $52.9 \%, P=0.049$; delayed: $54.0 \%$ versus $38.7 \%, P=0.004)$. $^{22,23}$

Dexamethasone was given with the $5-\mathrm{HT}_{3}$ receptor antagonists in only a small number of patients (5\%) in only one of these studies, ${ }^{22}$ and it remains to be determined if the differences in CR would persist if dexamethasone was used in a randomized controlled trial. Importantly, the analysis of the Functional Living Index-Emesis (FLIE) data from these two randomized trials demonstrated that improved control of CINV prevented delayed nausea and vomiting from impacting the daily life activities of significantly more patients receiving palonosetron than the comparator drug. ${ }^{30}$

In another study, 667 patients receiving highly emetogenic chemotherapy (HEC) (cisplatin, $\geq 60 \mathrm{mg} / \mathrm{m}^{2}$ ) received one of two doses of palonosetron $(0.25 \mathrm{mg}$ or $0.75 \mathrm{mg})$ or ondansetron (32 mg) pre-chemotherapy. Sixty-seven percent of the patients in all three study arms also received dexamethasone. Single-dose palonosetron was as effective as ondansetron in preventing acute CINV and with dexamethasone pretreatment, its effectiveness was significantly increased over ondansetron throughout the 5-day postchemotherapy period. ${ }^{25}$

In an analysis of the patients in the above studies who received repeated cycles of MEC or HEC, Cartmell et al $^{31}$ reported that the $\mathrm{CR}$ rates for both acute and delayed CINV were maintained with the single intravenous doses of palonosetron with or without concomitant corticosteroids.

Based on the above studies, palonosetron was approved by the FDA in July, 2003 for the prevention of acute nausea and vomiting associated with initial and repeat courses of MEC and HEC; and for the prevention of delayed nausea and vomiting associated with initial and repeat courses of MEC.

\section{Recent studies}

Phase II

Grote et $\mathrm{al}^{33}$ investigated the use of palonosetron in combination with aprepitant, a NK-1 receptor antagonist, ${ }^{21}$ for 
the prevention of CINV in patients receiving MEC or HEC. The multicenter, open-label study evaluated the safety and efficacy of a single intravenous dose of palonosetron, $0.25 \mathrm{mg}$ on day 1 prior to chemotherapy in combination with three consecutive days of oral aprepitant (125 mg on day 1 and $80 \mathrm{mg}$ on days 2 and 3 ), and three consecutive days of oral dexamethasone (12 $\mathrm{mg}$ on day 1 and $8 \mathrm{mg}$ on days 2 and 3 ). Fifty-eight patients were enrolled in the study and $80 \%$ were women. Breast cancer was the predominant tumor type followed by colorectal cancer, lung cancer, and malignant lymphoma. Twenty-four of the patients received anthracycline/cyclophosphamide combination chemotherapy.

A CR was observed in $88 \%$ of patients in the first 24 hours post-chemotherapy (acute), 78\% days 2 to 5 (delayed), and $78 \%$ days 1 to 5 (overall). No nausea was observed in $71 \%$ of patients in the acute period, $53 \%$ in the delayed period, and $52 \%$ overall. There were no significant adverse events during the study. It was concluded that palonosetron with dexamethasone and aprepitant was a highly effective regimen for patients at risk for CINV.

The comparative efficacy and tolerability of palonosetron and ondansetron/dolasetron were assessed in a retrospective analysis using pooled data from 171 elderly patients (age $\geq 65$ years) with cancer enrolled in 2 randomized double-blind, phase III clinical studies comparing single intravenous doses of these anti-emetic agents given prior to receipt of MEC. The CR was significantly higher in the palonosetron group than in the ondansetron/dolasetron group in the five days following chemotherapy, suggesting that palonosetron is safe and effective in elderly patients with cancer receiving emetogenic chemotherapy. ${ }^{34}$

Hajdenberg et $\mathrm{al}^{35}$ reported the results of another multicenter, open-label study evaluating the use of palonosetron $(0.25 \mathrm{mg})$ and dexamethasone $(8 \mathrm{mg})$ prior to patients receiving moderately to highly emetogenic chemotherapy. Thirty-two patients completed the study and $62 \%$ were women. Breast cancer was the predominant tumor type followed by colorectal cancer and lung cancer. Carboplatin, paclitaxel, doxorubicin, and cyclophosphamide combination chemotherapy regimens were the most common in this study.

A CR was observed in $84 \%$ of patients in the first 24 hours post-chemotherapy (acute), 59\% of patients during days 2 to 5 (delayed), and $59 \%$ days 1 to 5 (overall period). No nausea was observed in $78 \%$ of patients in the acute period, and $50 \%$ in the overall period. No significant adverse events were reported in the study.
A recent phase II trial of olanzapine and palonosetron for the prevention of $\mathrm{CINV}^{36}$ has been reported. Olanzapine had been previously shown to be a safe and effective agent for the prevention of CINV in chemotherapy naïve cancer patients. ${ }^{37}$ In the phase II trial, the anti-emesis regimen was $10 \mathrm{mg}$ of oral olanzapine, $0.25 \mathrm{mg}$ of intravenous palonosetron, and dexamethasone ( $20 \mathrm{mg}$ for HEC and $8 \mathrm{mg}$ for MEC) on the day of chemotherapy, day 1 , and $10 \mathrm{mg} /$ day of oral olanzapine alone on days 2 to 4 after chemotherapy. Forty chemotherapy-naïve patients (median age 60 years, range 38 to 84; 22 females; ECOG PS 0, 1) consented to the protocol and all were evaluable. The percentage of patients with a CR was $100 \%$ for the acute period ( 24 hours post-chemotherapy), $75 \%$ for the delayed period (days 2 to 5 post-chemotherapy), and $75 \%$ for the overall period ( 0 to 120 hours) for 8 patients receiving $\mathrm{HEC}$ (cisplatin $>70 \mathrm{mg} / \mathrm{m}^{2}$ ). CR was $97 \%$ for the acute period, $75 \%$ for the delayed period, and $72 \%$ for the overall period in 32 patients receiving $\mathrm{MEC}$ (doxorubicin, $>50 \mathrm{mg} / \mathrm{m}^{2}$ ). In the patients receiving $\mathrm{HEC}$, the percentage of patients without nausea (0, scale 0-10, M.D. Anderson Symptom Inventory) was 100\% in the acute period, $50 \%$ in the delayed period, and $50 \%$ in the overall period. In patients receiving $\mathrm{MEC}$, the percentage without nausea was $100 \%$ in the acute period, $78 \%$ in the delayed period, and $78 \%$ in the overall period. There were no Grade 3 or 4 toxicities and no significant pain, fatigue, disturbed sleep, memory changes, dyspnea, lack of appetite, drowsiness, dry mouth, mood changes or restlessness experienced by the patients. CR and control of nausea in subsequent cycles of chemotherapy (35 patients, cycle 2; 31 patients cycle 3; 23 patients, cycle 4) were equal to or greater than cycle one. The combination of olanzapine and palonosetron with dexamethasone given only on the day of chemotherapy was safe and highly effective in controlling acute and delayed CINV in patients receiving HEC and MEC.

In a phase II, multicenter, randomized, double-blind, parallel, comparative clinical trial, the efficacy and safety of palonosetron $(0.25 \mathrm{mg})$ was compared with granisetron ( $3 \mathrm{mg}$ ) in Chinese cancer patients receiving HEC. In 208 patients, palonosetron was not inferior to granisetron in preventing acute or delayed chemotherapy-induced vomiting. ${ }^{32}$ Adverse events were low among the two groups.

Einhorn et $\mathrm{al}^{38}$ reported on 41 adult men who received 5 days of cisplatin $\left(20 \mathrm{mg} / \mathrm{m}^{2}\right)$ and were treated with palonosetron, $0.25 \mathrm{mg}$ intravenously on days 1,3 , and 5 and dexamethasone, $20 \mathrm{mg}$ iv on days 1 and 2, $8 \mathrm{mg}$ bid orally on days 6 and 7 , and $4 \mathrm{mg}$ bid orally on day 8 . Fifty-one percent of the patients had no emetic episodes on days 
1 to 5 (range $88 \%$ day 1 to $68 \%$ on day 4 ) and $83 \%$ had no emesis on days 6 to 9 . The majority of the patients had no moderately to severe nausea and did not require rescue medications over the nine-day observation period. The authors concluded that 3 doses of palonosetron and 5 doses of dexamethasone over an 8-day period effectively prevented both emesis and significant nausea in the majority of patients with germ cell tumors receiving multiple-day cisplatin-based chemotherapy. The regimen used appeared to be an improvement over historical controls.

The current recommendation for patients receiving multi-day chemotherapy is to give a first-generation $5-\mathrm{HT}_{3}$ receptor antagonist plus dexamethasone daily during each day of chemotherapy. ${ }^{39}$ The daily first-generation $5-\mathrm{HT}_{3} /$ dexamethasone regimen appears to be at least partially effective in controlling acute CINV, but it is not very effective in controlling delayed CINV. The Einhorn et $\mathrm{a}^{38}$ study suggests that agents that control both acute and delayed CINV have potential as preventative agents in patients receiving multipleday chemotherapy.

Musso et $\mathrm{al}^{40}$ used palonosetron as prophylaxis for CINV on the first day of chemotherapy and dexamethasone throughout the entire period of chemotherapy for the prevention of CINV in patients receiving multiple-day chemotherapy. A second dose of palonosetron was given if breakthrough emesis occurred 72 hours after the first administration. Compared to a retrospective control group who received single-dose ondansetron, dexamethasone throughout, and metoclopramide for breakthrough emesis, the palonosetron group had less CINV and rescue was more successful.

\section{Phase III}

Saito et $\mathrm{al}^{26}$ conducted a double-blind, double-dummy, randomized, comparative phase III trial in 1143 patients receiving HEC (cisplatin or the combination of an anthracycline and cyclophosphamide). Patients were recruited from 75 institutions in Japan and were randomly assigned to either single-dose palonosetron $(0.75 \mathrm{mg})$ or granisetron $(40 \mu \mathrm{g} / \mathrm{kg})$ 30 minutes before chemotherapy on day 1 . Both groups also received dexamethasone, (16 $\mathrm{mg}$ iv) on day 1 followed by additional doses ( $8 \mathrm{mg}$ iv for patients receiving cisplatin and $4 \mathrm{mg}$ orally for patients receiving an anthracycline and cyclophosphamide) on days 2 and 3 . Of 555 patients in the palonosetron group, $418(75.3 \%)$ had a complete response during the first 24 hours (acute period) compared with 410 of 559 patients $(73.3 \%)$ in the granisetron group. During the delayed period, 315 of 555 patients $(56.8 \%)$ had a complete response in the palonosetron group compared with 249 of
559 patients $(44.5 \%)$ in the granisetron group $(P<0.0001)$. When administered with dexamethasone, palonosetron prevented CINV which was non-inferior to granisetron in the acute period and better than granisetron in the delayed period, with a comparable safety profile for the two treatments.

Two randomized, double-blind studies evaluated the efficacy and safety of palonosetron versus placebo in preventing post-operative nausea and vomiting (PONV). A single $0.075 \mathrm{mg}$ iv dose of palonosetron prior to surgery effectively reduced the severity of nausea 24 hours after surgery and delayed the time to emesis and treatment failure. ${ }^{41,42}$ Based on these studies, palonosetron was approved by the FDA in March, 2008 for the prevention of PONV for up to 24 hours following surgery.

\section{Chemistry}

Palonosetron $\mathrm{HCl}$ is an isoquinolone hydrochloride with an empirical formula of $\mathrm{C} 19 \mathrm{H} 24 \mathrm{~N} 2 \mathrm{O} \mathrm{HCl}$ and a molecular weight of 332.87. Palonosetron exists as a single isomer and its structural formula is shown in Figure 1. It is freely soluble in water, soluble in propylene glycol, and slightly soluble in ethanol and 2-propanol. Palonosetron injection is a sterile, clear, colorless, nonpyrogenic, isotonic, buffered solution for intravenous administration.

\section{Pharmacodynamics}

Palonosetron is a $5-\mathrm{HT}_{3}$ receptor antagonist with a high binding affinity for this receptor and little or no affinity for other receptors. $5-\mathrm{HT}_{3}$ receptors are located on the nerve terminals of the vagus in the periphery and centrally in the chemoreceptor trigger zone of the area postrema. ${ }^{21}$ Animal studies have demonstrated that chemotherapy agents

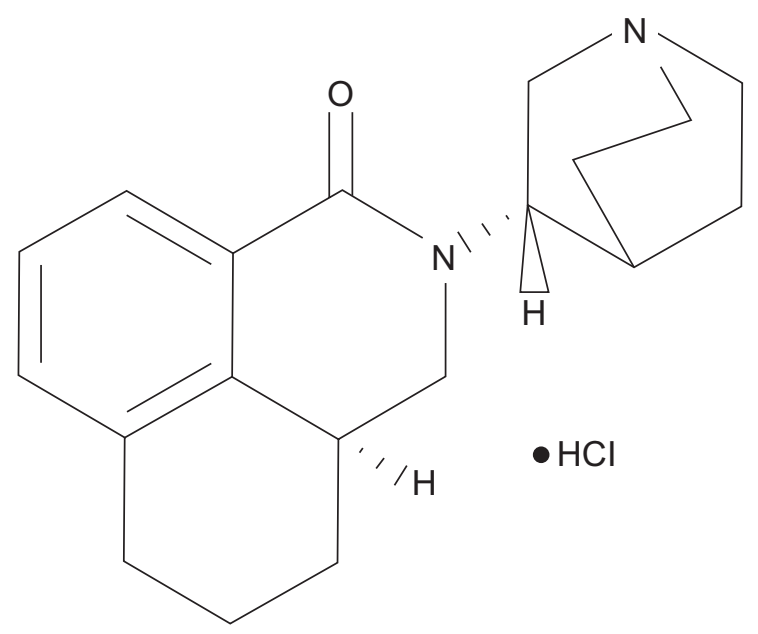

Figure I Structural formula of palonosetron. 
produce nausea and vomiting by releasing serotonin from the enterochromaffin cells of the small intestine and that the released serotonin then activates the $5-\mathrm{HT}_{3}$ receptors located on the vagal afferents to initiate the vomiting reflex. Palonosetron demonstrated a 5- $\mathrm{HT}_{3}$ receptor binding affinity at least 30-fold higher than other $5-\mathrm{HT}_{3}$ receptor antagonists (Table 2). ${ }^{24,28}$ Rojas et $\mathrm{al}^{43}$ recently reported that palonosetron exhibited allosteric binding and positive cooperativity when binding to the $5-\mathrm{HT}_{3}$ receptor with simple bimolecular binding for both granisetron and ondansetron. Palonosetron also appeared to affect receptor function. Differences in binding and effects on receptor function may explain some differences between palonosetron and the first-generation $5-\mathrm{HT}_{3}$ receptor antagonists. ${ }^{28}$

\section{Pharmacokinetics and metabolism}

After intravenous dosing of palonosetron in healthy subjects and cancer patients, an initial decline in plasma concentration is followed by a slow elimination from the body. Mean maximum plasma concentration and area under the concentration - time curves are generally dose-proportional over the dose range of 0.3 to $90 \mu \mathrm{g} / \mathrm{kg}$ in healthy subjects and in cancer patients. ${ }^{24}$ Palonosetron has a volume of distribution of approximately $8.3 \pm 2.5 \mathrm{~L} / \mathrm{kg}$ and is $62 \%$ bound to plasma proteins.

Palonosetron is eliminated from the body through renal excretion and metabolic pathways. After a single intravenous dose of $10 \mu \mathrm{g} / \mathrm{kg}{ }^{14} \mathrm{C}$ palonosetron, approximately $80 \%$ of the dose was recovered within 144 hours in the urine with palonosetron representing approximately $40 \%$ of the administered dose. The mean terminal elimination half-life is approximately 40 hours (Table 2). ${ }^{24,28}$

Approximately $50 \%$ of palonosetron is metabolized to form two primary metabolites. Each of these metabolites has less than $1 \%$ of the $5-\mathrm{HT}_{3}$ receptor antagonist activity of palonosetron. The metabolic pathways are mediated via multiple CYP enzymes, including CYP2D6, and to a lesser extent, CYP3A and CYP1A2. Clinical pharmacokinetic parameters are not significantly different between poor and extensive CYP2D6 metabolizers. In vitro studies have indicated that palonosetron is not an inhibitor of CYP1A2, CYP2A6, CYP2C9, CYP2D6, CYP2E1, and CYP3A4/5, nor did it induce the activity of CYP1A2, CYP2D6, or CYP3A4/5. The potential for clinically significant drug interactions with palonosetron appears to be low. . $2,28,29^{2}$

In controlled clinical trials, palonosetron has been safely administered with corticosteroids, analgesics, anti-emetics, antispasmodics, and anticholinergic agents. ${ }^{22-26,28,31,33,44,45}$
Palonosetron did not inhibit the antitumor activity of five chemotherapeutic agents (cisplatin, cyclophosphamide, cytarabine, doxorubicin, and mitomycin C) in murine tumor models. $^{29}$

Population pharmacokinetic analysis did not reveal any differences between cancer patients $\geq 65$ years of age and younger patients. Mild to moderate renal impairment does not significantly affect palonosetron pharmacokinetics and hepatic impairment does not significantly affect total body clearance of palonosetron compared to healthy patients. Therefore, dosage adjustment is not necessary for patients with renal or hepatic impairment. ${ }^{28,45}$

\section{Safety and tolerability}

Results from the phase II dose-ranging study and phase III comparative studies in patients receiving MEC and HEC were the basis for approval of palonosetron by the FDA. ${ }^{22-25,31}$ In these studies, patients were exposed to a wide range of palonosetron doses, up to 25 times the approved palonosetron dose of $0.25 \mathrm{mg}$. The adverse reactions reported were the most common reactions reported for the $5-\mathrm{HT}_{3}$ receptor antagonist class, headache, and constipation. All other reactions occurred at an incidence of $\leq 1 \%$ in patients treated with $0.25 \mathrm{mg}$ of palonosetron. ${ }^{28,46}$

There were no clinically relevant differences seen among palonosetron, ondansetron, or dolasetron in laboratory, electrocardiographic, or vital sign changes. ${ }^{28} \mathrm{~A}$ clinical study in male and female volunteers showed that the cardiac profile of palonosetron is the same as placebo. There were no electrocardiographic or dose response effects, including QTc prolongation, of palonosetron up to a $2.25 \mathrm{mg}$ iv dose, a 9-fold safety margin. ${ }^{47}$ In phase III studies, palonosetron was safely administered in 192 patients with pre-existing cardiac impairment. ${ }^{28}$

The safety of palonosetron administered over repeated cycles of MEC or HEC was demonstrated in an open-label multinational phase III study ${ }^{31,48}$ which enrolled patients who had participated in one of three phase III comparator trials. $^{22,23,25}$

Palonosetron at 3 times the approved dose was well tolerated over repeated cycles with no unexpected adverse events. There were no clinically relevant differences among cycles, and the number of adverse reactions did not increase from cycle one to cycle three.

\section{Conclusion}

The first-generation 5- $\mathrm{HT}_{3}$ receptor antagonists (dolasetron, granisetron, ondansetron, tropisetron, ramosetron, and azasetron) 
have significant and similar efficacy in the prevention of acute CINV for patients receiving MEC and HEC. However, these agents do not appear to have significant efficacy in the prevention of delayed CINV.

Phase III comparative studies suggest that the use of palonosetron alone improves the complete response rate of acute and delayed emesis, when compared with the use of the first-generation $5-\mathrm{HT}_{3}$ receptor antagonists alone in patients receiving MEC. In combination with dexamethasone, palonosetron is effective in controlling acute and delayed CINV in patients receiving HEC. With dexamethasone pretreatment, single-dose palonosetron was as effective as ondansetron and granisetron in preventing acute CINV, and with dexamethasone pretreatment, palonosetron's effectiveness was significantly increased over ondansetron throughout the 5-day post-chemotherapy period and significantly better than granisetron in the delayed period.

The complete response rates for palonosetron appear to be maintained over repeated cycles of chemotherapy for patients receiving either MEC or HEC.

In phase II trials involving patients receiving MEC and HEC, palonosetron was combined with dexamethasone and aprepitant in one study, with dexamethasone in another study, and with dexamethasone and olanzapine in a third study. These combinations were safe and highly effective in controlling CINV. The effect of palonosetron on the control of acute and delayed CINV in combination with dexamethasone and in combination with other anti-emetics in patients receiving MEC and HEC and will be the subject of further studies in patients receiving emetogenic chemotherapy.

As suggested in 2 phase II clinical trials, palonosetron may have marked effectiveness in preventing CINV in patients receiving multiple-day chemotherapy due to its demonstrated efficacy in preventing both acute and delayed CINV.

In addition to the FDA indications for the prevention of acute and delayed CINV (July 2003), palonosetron received FDA approval in March 2008 for the prevention of PONV based on 2 randomized, double-blind studies.

The safety and tolerability of palonosetron has been well documented in multiple, large phase III trials. There were no clinically relevant differences seen among palonosetron, ondansetron, or dolasetron in laboratory, electrocardiographic, or vital sign changes over multiple cycles of chemotherapy. The adverse reactions reported were the most common reactions reported for the $5-\mathrm{HT}_{3}$ receptor antagonist class.

The control of nausea in patients receiving MEC and HEC remains a significant problem. The current first-generation
$5-\mathrm{HT}_{3}$ receptor antagonists, while very effective in controlling emesis in a large percentage of patients in the initial 24 hours post-chemotherapy, nevertheless fail to adequately control nausea in a significant number of patients. The recent palonosetron studies provided some improvement in the control of nausea, sometimes to a clinically and statistically significant degree.

A recent phase II study using olanzapine in combination with palonosetron and dexamethasone showed promise in controlling acute and delayed nausea in patients receiving MEC and HEC.

Based on initial and recent clinical studies, palonosetron is highly effective in controlling acute and delayed CINV in patients receiving either MEC or HEC. Compared to the first-generation $5-\mathrm{HT}_{3}$ receptor antagonists, palonosetron has equivalent efficacy in controlling acute CINV and appears to be more effective in controlling delayed CINV.

Questions that have arisen concerning palonosetron include: Does palonosetron differ in mechanism of action from the current first-generation $5-\mathrm{HT}_{3}$ agents? Does the higher binding affinity, the longer half-life, or the high potency account for the clinical differences between palonosetron and the first-generation 5- $\mathrm{HT}_{3}$ receptor antagonists? Does palonosetron affect $5-\mathrm{HT}_{3}$ receptors in a different way or in a different location than the first-generation $5-\mathrm{HT}_{3}$ receptor antagonists accounting for its apparent efficacy in delayed CINV?

In studies investigating the mechanism of action, palonosetron has been found to exhibit allosteric binding and positive cooperativity when binding to the $5-\mathrm{HT}_{3}$ receptor. This is in contrast to the simple bimolecular binding for both granisetron and ondansetron. Palonosetron also appeared to affect receptor function in these studies. The differences in binding and the effects on receptor function may explain the differences in the clinical effects between palonosetron and the first-generation $5-\mathrm{HT}_{3}$ receptor antagonists.

The early palonosetron studies demonstrated that palonosetron was not inferior to the first generation $5-\mathrm{HT}_{3}$ receptor antagonists in controlling acute CINV and may have some improved efficacy in controlling delayed CINV. The criticisms of these studies were that they were designed as noninferiority studies and were done without the use of dexamethasone. A recent study has shown that in combination with dexamethasone, palonsetron was equivalent to granisetron in controlling acute CINV but better than granisetron in controlling delayed CINV. The palonosetron dose used in this study was $0.75 \mathrm{mg}$ instead of the FDA-approved $0.25 \mathrm{mg}$ dose, but previous phase II and III studies have shown these two doses to be equivalent. 
The introduction of 5- $\mathrm{HT}_{3}$ receptor antagonists for the prevention of chemotherapy-induced nausea and emesis has resulted in a major improvement in supportive care. ${ }^{21}$ Treatment guidelines for the prevention of CINV recommended by a number of international groups ${ }^{49-52}$ suggest the use of a $5-\mathrm{HT}_{3}$ receptor antagonist and dexamethasone pre-chemotherapy for the prevention of acute CINV and the use of dexamethasone with or without a $5-\mathrm{HT}_{3}$ receptor antagonist following chemotherapy for the prevention of delayed nausea and vomiting in patients receiving MEC. The guidelines ${ }^{49-52}$ have also recommended the addition of aprepitant, ${ }^{6,21}$ a NK-1 receptor antagonist, to a 5-HT 3 receptor antagonist and dexamethasone pre-chemotherapy and to dexamethasone post-chemotherapy for patients receiving HEC or receiving the combination of cyclophosphamide and doxorubicin, commonly used in patients with breast cancer receiving adjuvant chemotherapy.

It should be noted that all four of the $5-\mathrm{HT}_{3}$ receptor antagonists available in the United States are approved for the prevention of acute CINV, and palonosetron is the only $5-\mathrm{HT}_{3}$ receptor antagonist approved for the control of delayed CINV (in patients receiving MEC). The Multinational Association of Supportive Care in Cancer (MASCC) anti-emesis guidelines, and the American Society of Clinical Oncology (ASCO) recent anti-emesis guidelines have stated that at appropriate dosages, all of the $5-\mathrm{HT}_{3}$ antagonists are interchangeable without preference for any agent. The National Comprehensive Cancer Network (NCCN) anti-emetic guidelines for the prevention of CINV , have now listed palonosetron as the preferred $5-\mathrm{HT}_{3}$ receptor antagonist. Based on the recent studies on palonosetron, it appears that there are distinct scientific and clinical differences between palonosetron and the first-generation $5-\mathrm{HT}_{3}$ receptor antagonists. When new guidelines are issued by ASCO and MASCC, it is assumed that these differences will be included.

Due to its efficacy in both acute and delayed CINV, palonosetron has high potential for controlling CINV in the settings of multiple-day chemotherapy and bone marrow transplantation. Two phase II studies have demonstrated the efficacy of palonosetron in controlling CINV in patients receiving multiple-day chemotherapy. It is anticipated that phase III studies comparing palonosetron to the firstgeneration $5-\mathrm{HT}_{3}$ receptor antagonists will show a marked improvement in the control of CINV in patients receiving multi-day chemotherapy.

Palonosetron should be further studied for the control of nausea and emesis in combination with dexamethasone, aprepitant and/or olanzapine. Future research may answer if nausea and emesis can be better controlled with these combinations. Such studies may not only provide additional options for the control of acute and delayed CINV, but may also provide new information on the mechanism of CINV.

Clinicians and other healthcare professionals who are involved in administering chemotherapy should be aware that studies have strongly suggested that patients experience more acute and delayed CINV than is perceived by practitioners, and patients often do not receive adequate prophylaxis. In addition, it is essential to emphasize that the current and new agents have been used as prophylaxis for acute and delayed CINV and have not been studied for use in established CINV.

\section{Disclosure}

The author declares no conflicts of interest.

\section{References}

1. Lachaine J, Yelle L, Kaizer L, Dufour A, Hopkins S, Deuson R. Chemotherapy-induced emesis: quality of life and economic impact in the context of current practice in Canada. Supp Cancer Therapy. 2005;2:181-187.

2. Cohen L, de Moor CA, Eisenberg P, et al. Chemotherapy-induced nausea and vomiting: incidence and impact on patient quality of life at community oncology settings. Support Care Cancer. 2007;15(5):497-503.

3. Hickok JT, Roscoe JA, Morrow GR, King DK, Atkins JN, Fitch JR. Nausea and emesis remain significant problems of chemotherapy despite prophylaxis with 5- Hydroxytryptamine-3 antiemetics. Cancer. 2003;97:2880-2886.

4. Grunberg SM, Deuson R, Mavros P, et al. Incidence of chemotherapyinduced nausea and emesis after modern anti-emetics: perception versus reality. Cancer. 2004;100:2261-2268.

5. Grunberg SM, Osoba D, Hesketh PJ, et al. Evaluation of new antiemetic agents and definition of antineoplastic agent emetogenicity-an update. Support Care Cancer. 2005; 13:80-84.

6. Navari RM, Province PS. Emerging drugs for chemotherapy-induced emesis. Expert Opin Emerging Drugs. 2006;11:137-151.

7. Simpson K, Spencer CM, McClellan KJ. Tropisetron: an update of its use in the prevention of chemotherapy-induced nausea and vomiting. Drugs. 2000;59:1297-1315.

8. Kimura E, Niimi E, Watanabe A, et al. Study on clinical effect of a continuous intravenous infusion of azasetron against nausea and vomiting induced by anticancer drugs including CDDP. Gan To Kagaku Ryoho. 1996;23:477-481.

9. Taguchi T, Tsukamoto F, Watanabe T, et al. Usefulness of ramosetron hydrochloride on nausea and vomiting in CMF or CEF therapy for breast cancer. Gan To Kagaku Ryoho. 1999;26:1163-1170.

10. Hesketh PJ. Comparative review of 5-HT3 receptor antagonists in the treatment of acute chemotherapy-induced nausea and vomiting. Cancer Invest. 2000;18:163-173.

11. Perez EA, Navari RM, Kaplan HG, et al. Efficacy and safety of different doses of granisetron for the prophylaxis of cisplatin-induced emesis. Support Care Cancer. 1997;5:31-37.

12. Hesketh PJ, Navari RM, Grote T, et al. Double blind randomized comparison of the antiemetic efficacy of intravenous dolasetron and intravenous ondansetron in the prevention of acute cisplatin-induced emesis in patients with cancer. J Clin Oncol. 1996;14:2242-2249. 
13. Navari RM, Gandara D, Hesketh $\mathrm{P}$, et al. Comparative clinical trial of granisetron and ondansetron in the prophylaxis of cisplatin-induced emesis. J Clin Oncol. 1995;13:1242-1239.

14. Navari RM, Koeller JM. Electrocardiographic and cardiovascular effects of the 5-hydroxytryptamine-3 receptor antagonists. Ann Pharmacother. 2003:37:1276-1286

15. Roila F, Warr D, Clark-Snow R, et al. Delayed emesis: moderately emetogenic chemotherapy. Support Care Cancer. 2005;13:104-108.

16. Latreille J, Pater J, Johnston D, et al. Use of dexamethasone and granisetron in the control of delayed emesis for patients who receive highly emetogenic chemotherapy. J Clin Oncol. 1998;16:1174-1178.

17. Navari RM, Madajcwicz S, Anderson N, et al. Oral ondansetron for the control of cisplatin-induced delayed emesis: a large, multicenter, double-blind, randomized comparative trial of ondansetron versus placebo. J Clin Oncol. 1995;13:2408-2416.

18. The Italian Group for Antiemetic Research. Dexamethasone alone or in combination with ondansetron for the prevention of delayed nausea and vomiting induced by chemotherapy. $N$ Engl J Med. 2000;342: 1554-1559.

19. Geling O, Eichler H. Should 5-hydroxytryptamine-3 receptor antagonists be administered beyond 24 hours after chemotherapy to prevent delayed emesis? systematic re-evaluation of clinical evidence and drug cost implications. J Clin Oncol. 2005;23:1289-1294.

20. Hickok JT, Roscoe JA, Morrow GR, et al. 5-HT 3 receptor antagonists versus prochlorperazine for control of delayed nausea caused by doxorubicin: a URCC CCOP randomized controlled trial. Lancet Oncol. 2005;6:765-772.

21. Navari RM. Pathogenesis-based treatment of chemotherapy-induced nausea and vomiting: Two new agents. J Support Oncol. 2003;1: 89-103.

22. Eisenberg P, Figueroa-Vadillo J, Zamora R, et al. Improved prevention of moderately emetogenic chemotherapy-induced nausea and vomiting with palonosetron, a pharmacologically novel $5-\mathrm{HT}_{3}$ receptor antagonist. Results of a phase III, single-dose trial versus dolasetron. Cancer. 2003;98:2473-2482.

23. Gralla R, Lichinitser M, Van Der Vegt S, et al. Palonosetron improves prevention of chemotherapy-induced nausea and vomiting following moderately emetogenic chemotherapy: Results of a double-blind randomized phase III trial comparing single doses of palonosetron with ondansetron. Ann Oncol. 2003;14:1570-1577.

24. Eisenberg P, MacKintosh FR, Ritch P, et al. Efficacy, safety, and pharmacokinetics of palonosetron in patients receiving highly emetogenic, cisplatin-based chemotherapy: a dose-ranging, clinical study. Ann Oncol. 2004;15:330-337.

25. Aapro MS, Grunberg SM, Manikhas GM, et al. A phase III, double blind,randomized trial of palonosetron compared with ondansetron in preventing chemotherapy-induced nausea and vomiting following highly emetogenic chemotherapy. Ann Oncol. 2006;17:1441-1449.

26. Saito M, Aogi K, Sekine I, et al. Palonosetron plus dexamethasone versus granisetron plus dexamethsone for prevention of nausea and vomting during chemotherapy: a double-blind, double-dummy, randomized, comparative phase III trial. Lancet Oncol. 2009;10: 115-124.

27. DeJonghe BC, Horn CC. Chemotherapy agent cisplatin induces 48-h Fos expression in the brain of a vomiting species, the house musk shrew (Suncus murinus). Am J Physiol Regul Integr Comp Physiol. 2009;294(4):R902-R911.

28. Aloxi (palonosetron $\mathrm{HCl}$ ) injection prescribing information. MGI Pharma, Inc., Bloomington, MN, 2003.

29. Cantoreggi S, Parisi S, Van Laar E, et al. Palonosetron, a new 5-HT antagonist does not alter antitumor efficacy of various chemotherapeutics in tumor bearing mice [abstract]. Clin Cancer Res. 2003; 9:6254S

30. Decker GM, DeMeyer ES, Kisko DL. Measuring the maintenance of daily life activities using the Fuctional Living Index-Emesis (FLIE) in patients receiving moderately emetogenic chemotherapy. J Support Oncol. 2006;4:35-41.
31. Cartmell AD, Ferguson S, Yanagihara R, et al. Protection against chemotherapy-induced nausea and vomiting is maintained over multiple cycles of moderately or highly emetogenic chemotherapy by palonosetron, a potent $5-\mathrm{HT}_{3}$ receptor antagonist [abstract]. Proceedings of the American Society of Clinical Oncology; 2003 May 31-June 03; Chicago.

32. Yu Z, Liu W, Wang L, et al. The efficacy and safety of palonosetron compared with Granisetron in preventing highly emetogenic chemotherapy-induced vomting in the Chinese cancer patients: a phaseII, multicenter, randimized, comparative clinical trial. Support Care Cancer. 2009;17:99-102.

33. Grote T, Hajdenberg J, Cartmell AD, et al. Palonosetron plus aprepitant and dexamethasone is a highly effective combination to prevent chemotherapy induced nausea and vomting after emetogenic chemotherapy. J Support Oncol. 2006;4:403-408.

34. Aapro MS, Macciocchi A, Gridelli C. Palonosetron improves prevention of chemotherapy induced nausea and vomiting in elderly patients. J Support Oncol. 2005;3:369-374.

35. Hajdenberg J, Grote T, Yee L, et al. Infusion of palonosetron plus dexamethasone is effective and safe for the prevention of chemotherapyinduced nausea and vomiting. J Support Oncol. 2006;4:467-471.

36. Navari RM, Einhorn LH, Loehrer PJ, et al. A phase II trial of olanzapine and palonosetron for the prevention of chemotherapy induced nausea and vomiting. Support Care Cancer. 2007;15:1285-1291.

37. Navari RM, Einhorn LH, Loehrer PJ, et al. A phase II trial of olanzapine for the prevention of chemotherapy-induced nausea and vomiting. Support Care Cancer. 2005;13:529-534.

38. Einhorn LH, Brames MJ, Dreicer R, et al. Palonosetron plus dexamethasone for the prevention of chemotherapy-induced nausea and vomiting in patients receiving multiple-day cisplatin chemotherapy for germ cell cancer. Support Care Cancer. 2007;15:1293-1300.

39. Navari RM. Prevention of emesis from multiple-day chemotherapy regimens. J Natl Compr Canc Netw. 2007;5:51-59.

40. Musso M, Scalone R, Bonanno V, et al. Palonosetron and dexamethasone for the Prevention of acute and delayed nausea and vomiting in patients receiving multi-day Chemotherapy. Support Care Cancer. 2009; 17:205-209.

41. Kovac AL, Eberhart L, Kotarski J, et al. A randomized double-blind study to evaluate the efficacy and safety of three different doses of palonosetron versus placebo in preventing postoperative nausea and vomiting over a 72-hour period. Anesth Analg. 2008;107:439-444.

42. Candiotti KA, Kovac AL, Melson TI, et al. A randomized double-blind study to evaluate the efficacy and safety of three different doses of palonosetron versus placebo for preventing postoperative nausea and vomting. Anesth Analg. 2008;107:445-451.

43. Rojas C, Stathis M, Thomas AG, et al. Palonosetron exhibits unique molecular interactions with the $5 \mathrm{HT}_{3}$ receptor. Anesth Analg. 2008;107:353-355.

44. Shah A, DeGroot T, Apseloff G. Pharmacokinetic evaluation and safety profile of a 15 minute versus 30 second infusion of palonosetron in healthy subjects. J ClinPharmacol. 2006;46:1139-1145.

45. Stoltz R, Cyong J, Shah A, Parisi S. Pharmacokinetic and safety evaluation of palonosetron, a $5 \mathrm{HT}_{3}$ receptor antagonist, in US and Japanese healthy subjects. J Clin Pharmacol. 2004;44:520-531.

46. Hajdenberg J. Safety profile of palonosetron, a pharmacologically distinct $5-\mathrm{HT}_{3}$ receptor antagonist recently approved for acute and delayed chemotherapy induced nausea [abstract]. Blood. 2003;102:510b.

47. Morganroth J, Parisi S, Moresino C, et al. High dose palonosetron does not alter parameters including $\mathrm{QT}_{\mathrm{C}}$ interval in healthy subjects: results of a dose-response, double blind, randomized, parallel E14 study of palonosetron versus moxifloxacin or placebo [abstract]. European $J$ Cancer Suppl. 2007;5(4):158.

48. Bissoli F, McGiuggan M, Bertazzoli M. Post-marketing experience of palonosetron confirms a favorable benefit/risk profile. Support Care Cancer. 2005;13(413):A04.

49. Kris MG, Hesketh PJ, Somerfield MR, et al. American Society of Clinical Oncology. Guideline for Antiemetics in Oncology: Update. J Clin Oncol. 2006;24:2932-2947. 
50. ASCO.org [homepage on the internet]. Alexandria, VA. American Society of Clinical Oncology; c2005-2009 [cited September 2009]. URL: http://www.asco.org/

51. NCCN.org [homepage on the internet]. Fort Washington, PA. The National Comprehensive Cancer Network; c2009 [cited September, 2009]. URL: http://www.ncen.org/
52. MASCC.org [homepage on the internet]. Metairie, LA. Multinational Association of Supportive Care in Cancer; c2009 [cited September, 2009]. Available from: http://www.mascc.org/.

\section{Publish your work in this journal}

Cancer Management and Research is an international, peer-reviewed open access journal focusing on cancer research and the optimal use of preventative and integrated treatment interventions to achieve improved outcomes, enhanced survival and quality of life for the cancer patient. The journal welcomes original research, clinical \& epidemiological studies, reviews \& evaluations, guidelines, expert opinion \& commentary, case reports \& extended reports. The manuscript management system is completely online and includes a very quick and fair peerreview system, which is all easy to use. Visit http://www.dovepress.com/ testimonials.php to read real quotes from published authors. 